Precocious Charms 
The publisher gratefully acknowledges the generous support of the Humanities Endowment Fund of the University of California Press Foundation. 


\section{Precocious Charms}

Stars Performing Girlhood in Classical Hollywood Cinema

\section{Gaylyn Studlar}

마

UNIVERSITY OF CALIFORNIA PRESS

Berkeley · Los Angeles • London 
University of California Press, one of the most distinguished university presses in the United States, enriches lives around the world by advancing scholarship in the humanities, social sciences, and natural sciences. Its activities are supported by the UC Press Foundation and by philanthropic contributions from individuals and institutions. For more information visit www.ucpress.edu.

Materials in this book have appeared in different form in three previously published articles: “Oh, 'Doll Divine': Mary Pickford, Masquerade, and the Pedophilic Gaze" was originally published in Camera Obscura I6, no. 3.48 (200I): I97-227 (C) Gaylyn Studlar; "Velvet's Cherry: Elizabeth Taylor and Virginal English Girlhood" appeared in Virgin Territory: Representing Sexual Inexperience in Film, ed. Tamara Jeffers McDonald (Detroit: Wayne State University Press, 2010), I 5-33. Copyright (C) 2010 Wayne State University Press. Used with permission by Wayne State University Press; “'Chi-Chi Cinderella': Audrey Hepburn as Couture Countermodel" was included in Hollywood Goes Shopping, ed. David Desser and Garth S. Jowett (Minneapolis: University of Minnesota Press, 2000): I 59-78.

University of California Press

Berkeley and Los Angeles, California

University of California Press, Ltd.

London, England

(C) 2013 by The Regents of the University of California

Library of Congress Cataloging-in-Publication Data

Studlar, Gaylyn.

Precocious charms : stars performing girlhood in classical Hollywood cinema / Gaylyn Studlar.

p. $\mathrm{cm}$.

Includes bibliographical references and index.

ISBN 978-0-520-25557-9 (cloth : alk. paper)

ISBN 978-0-520-27424-2 (pbk. : alk. paper)

I. Girls in motion pictures. 2. Teenage girls in motion pictures. 3. Motion pictures-United States-History2oth century. 4. Child actors-United States-History2oth century. I. Title.

PNI995.9.G57S65 20I3

$791.43^{\prime} 6523-\mathrm{dc} 23$

2012029630

Manufactured in the United States of America

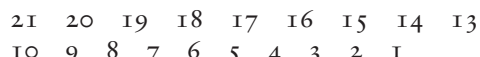

In keeping with a commitment to support environmentally responsible and sustainable printing practices, UC Press has printed this book on Rolland Enviro ı०o, a I00\% postconsumer fiber paper that is FSC certified, deinked, processed chlorine-free, and manufactured with renewable biogas energy. It is acid-free and EcoLogo certified. 
In memory of my parents, Irene and Joe Studlar, with gratitude for their love and for the sacrifices they made so that I could be an educated woman

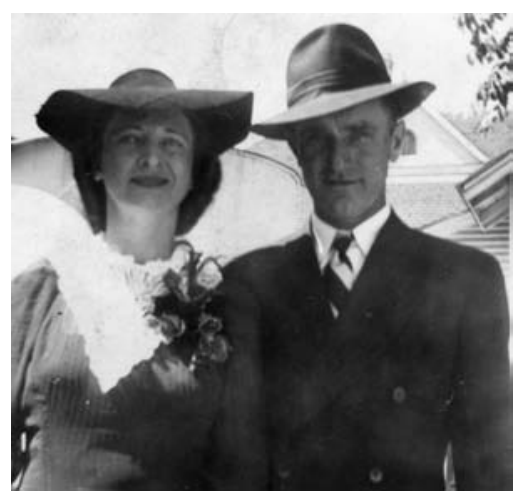


This page intentionally left blank 
I suppose she must have looked rather delightful, for Mrs.

Darling put her hand to her heart and cried, "Oh, why can't you remain like this for ever!"

-J.M. Barrie, Peter Pan and Wendy 
This page intentionally left blank 